\title{
SUSTAINABILITY AS AN IMPERATIVE COMPONENT OF EVALUATING BUSINESS MODELLS IN FINTECH
}

\author{
Rosita ZVIRGZDINA (D), Helena SKADINA, Iveta LININA (10) \\ Faculty of Business Administration, Turiba University, Graudu Street 68, LV-1058, Riga, Latvia \\ EE-mail: rosita@turiba.lv
}

\begin{abstract}
Purpose - the purpose of this research is to contribute to the business modelling in FinTech with criteria, which could FinTech companies to critically evaluate the performance of their business model, its relevance and timeliness, its compliance with set goals and value topicality.
\end{abstract}

Research methodology - in this research, authors used semi-structured interviews with continuous comparative analysis method and content analysis method.

Findings - this research forms the basis for conclusions about relevant business model elements and criteria, which deserve closer attention while modelling FinTech business and could be relevant for evaluating the FinTech business model for sustainability reasons.

Research limitations - in time, when there is no consistent theoretical approach to business modelling including aspects of sustainability, this could be the first step on the way of extending the business modelling theory and improving the practice.

Practical implications - predefined criteria will enable focusing on particular criteria in the context of time, costs, flexibility and quality within the business modelling and taking these indicators for measuring the performance of the model and manage the risk of getting commercially nonviable.

Originality/Value - business model tools typically do not create a space for considering how sustainability concerns may be integrated into the business modelling process.

Keywords: business model, business model dimension, FinTech, sustainability.

JEL Classification: M16, G23, F23, E37.

Conference topic: Contemporary Financial Management.

\section{Introduction}

"It has never been so easy to create an idea, to start a business and to immediately conquer the entire world market" (Matzler, 2016). Also, never before has it been possible to get out of the market so quickly because of emerging new business models. FinTech companies are pioneering several solutions which are focused on really revolutionary digital technologies (Wisniewski, 2016). They are engaging with their partners to implement viable propositions, but “...they can be made only marketable through a suitable business model" (Van Stel, Carree, \& Thurik, 2005). Some of them may offer discrete opportunities for catalyzing truly sustainable development. A variety of technologies is used by FinTech companies because of their relevance for future success. Many of them directly address the sustainability in the real economy, for instance, around data streams, protocols and security (Report of the Banking Environment Initiative Fintech Taskforce, 2017). Technology-driven solutions in FinTech offer great potential for success and development of the FinTech ventures but "have not yet been systematically harnessed to target this challenge" (Ivey Business Journal, 2013): although many FinTech innovation, incubation and acceleration efforts are operating on different scales, they are not typically focused on achieving sustainable development (BEI's Fintech Taskforce, 2017).

Business modelling is becoming a widespread topic in the literature as well as in the FinTech industry. But there is not a wide range of prepared or predefined tools available in order to support FinTech companies by checking their business models for sustainability reasons. This paperwork aims to close this gap and qualifies to get nearer to the development of tools set for FinTech companies. The authors share the opinion that FinTech companies would very appreciate it if their management could use some predefined tools as a standard approach to measure, control and

(C) 2019 Authors. Published by VGTU Press. This is an open-access article distributed under the terms of the Creative Commons Attribution (http://creativecommons.org/licenses/by/4.0/) License, which permits unrestricted use, distribution, and reproduction in any medium, provided the original author and source are credited. 
maintain its business model in terms of sustainability, because "the pressure to operate sustainably has significantly increased" (Müller, 2017). It doesn't mean that companies don't have to work out their own systemic approach and include the sustainability indicators or measurement tools that support them to model "in a manner that generates shared value creation for all stakeholders including the environment and society" (Konnerz, Rohrbeck, \& Knab, 2011). All together would become a great combination and added value for managers on the way to sustainable FinTech future. For the authors of this research, who are working in the FinTech industry for years, it could help to implement these criteria in their current business area.

Until now there is no consistent theoretical approach to the concept of a Business model in the literature; not many types of research' authors refer to the aspects of sustainability while writing about FinTech business modeling in the sense of dimensions which are related to the current economic, social and environmental context as well as time, costs, flexibility and quality: the number of studies identified in the EBSCO database for the period from 2015 to 2019 is 2 (EBSCO, 2019). This indicates that this industry is still very young: it is considered that the financial crisis of 2008 was the occurrence that triggered a new wave of business and investment (Menat, 2016), but its rapid growth is not taken into account sufficiently enough. This would be a possibility to extend the business model theory and improve the practice.

The aim of this research is to determine which business model dimensions are particularly affected by the risk of unsustainability or, in other words, which of them have to be particularly checked for sustainability reasons by company's management in terms of time, costs, flexibility and quality, and to propose certain criteria which could be used for testing the current business model for sustainability reasons.

Various methods were used in the research: the theoretical part consists of the scientific literature analysis. Semistructured interviews with 3 FinTech experts (Olegs Chernishevs (OC), Mareks Rudovičs (MR), Poul Bondarenko (PB), representing Fin Tech industry (E-Money Institution (ENIM)) of Malta (OC); short-term lending company (PLK) of Russia (MR); Payment Institution of Great Britain (PB), were conducted during the course of the research. Semistructured interviewing, according to Bernard, provide reliable, comparable qualitative data (Bernard, 1988). The choice of experts was based on the diversity of their expertise and completely different and unrelated areas of FinTech. Taking into account, that the internationally created business models in FinTech have also become one of the sustainability criteria, this symbiosis, in the authors' opinion, provides better results of the research. The data are presented in the form of Tables.

In this research authors used a continuous comparative analysis method, using open coding, level 2 coding, axial coding and content analysis method with the inductive and deductive approach as well as content analysis method (Martinsone, Pipere, \& Kamerade, 2016). In interviews, experts were asked to determine those business model dimensions which are affected by the risk of unsustainability the most and to assess the influence of indicators on business model dimensions.

The result of this research forms the basis for conclusions about relevant business model dimension elements and criteria within them which deserve closer attention while modelling FinTech business and could be relevant for evaluating FinTech business model for sustainability reasons as well as about business model dimensions which considering the time, costs, flexibility and quality indicators are affected the most and have to be assessed according to these indicators.

By means of predefined criteria within the business model dimensions, FinTech companies will be able to focus on these criteria as to most important while business modelling. By means of business model dimensions which considering the time, costs, flexibility and quality indicators are affected the most companies will be able to take these particular indicators for measuring the performance of these dimensions and simultaneously manage the risk of getting commercially nonviable.

\section{Literature review}

The framework of a "business model" might provide a structured way for sustainable business thinking by mapping the purpose, opportunities for value creation across the network and value capture (how to generate revenue) in companies (Castilla-Rubio, Zadek, \& Robins, 2016). A clear statement of the business model enables a company to achieve a robust understanding of what it is seeking to achieve and the associated threats and opportunities (Bocken, Rana, \& Short, 2015). A comprehensive description of the business model provides all stakeholders with insight into the key dependencies for the company. Consequently, the success and initial survival of FinTechs is largely built upon the ability of FinTech entrepreneurs to describe their business logic, value network and position of the company in the financial industry value system to investors (Osterwalder, Pigneur, \& Tucci, 2005).

A business model itself constitutes a major instrument for generating crucial knowledge for the identification of the factors (i.e. business model dimensions, characteristics or components) that are relevant for success and development of FinTech companies. The term FinTech has turned into a mainstream benchmark for innovation in the financial sector, the digitalization of the financial services today is the result of an ongoing process of digital transformation that has taken place throughout the last century (Roeder et al., 2018). Digital technologies brought into play by FinTech 
companies are only profitable to the extent that they can be made marketable through a suitable business model (Van Stel et al., 2005).

The popularity of the term is enormous and the scientific research on business models is rapidly growing but there is still no common definition of what a business model is and how it is composed: from the great variety of the intentions in the literature as well as the own experience of the authors it can be concluded that a business model is a logical and contemplated interplay of company's decisions, business activities and participants, which describes the place, time and reason for business (Mitchell \& Coles, 2003); the benefits for customers and partners (Schallmo, 2013); the ways in which customers and partners benefit (Schallmo, 2013); the mechanism of service creation and participants in its provision (Gassmann et al, 2013); the way in which benefit translates into profit (Schallmo, 2013); profit reallocation way (Bieger \& Reinhold, 2011) and the involvement and placement of technologies for creating company value and promote operational efficiency of a company (Matzler, 2016). The business model concept could be seen as " $a$ new unit of analysis, offering a systemic perspective on how to 'do business, 'encompassing boundary-spanning activities and focusing on value creation as well as on value capture" (Roeder et al, 2018).

Related to the theory of Schallmo, there are questions to be answered before modelling business or changing it, which characterize and define the whole scope of possible aspects in each dimension of a business model (Schallmo, 2013). For example, if a company is modelling its customer dimension, questions should be asked about the customer segments, for example, how is the company going to reach its customers, which ways for what segment could be used to reach its customers and how should the planned relationship look like in order to be a long term relationship as well as which determinants are of importance in keeping a sustainable relationship with customers, partners and other market players in order to be successful and comply with the vision and goals of the company (Schallmo, 2013)? When these and other questions related to the business model dimensions are answered, the company has to set up critical success criteria in order to measure the implementation success and to form a necessary information volume for its Management. The company must be able to understand what is happening now and make it easier to decide and plan for future actions and activities. These are criteria about "the condition and trajectory of a system and why certain trends occur in specified contexts" (Bell \&Morse, 2008).

These criteria are crucial for the management of any company: they provide the ability to capture the necessary information about "how valued attributes are changing over time" (Latawiez \& Agol, 2015) and can be called the elements of early warning or monitoring system, they also can be seen as indicators that determine whether the created and implemented elements or dimensions of a FinTech business model confront the risk of unsustainability. Which criteria are responsible? What perspective should be used for the defining of them? Time, which indicates whether the business model elements are able to provide the services of the company timely; costs, or rather, low costs, which business model elements generate or, in other words, the model elements may not lead to additional expenses; quality, which ensures that all customer needs are satisfied; Flexibility, which makes it possible for re-emerged customer needs to be timely and easily adopted (Schallmo, 2013). In the research part of this paper the authors, based on experts' point of view, determine criteria that are responsible for as well as determine those business model dimensions which are affected by the risk of unsustainability the most or, in other words, have to be checked for this probability in order to ensure a sustainable future of a FinTech company.

Sustainability has often been defined as how biological systems endure and remain diverse and productive (UN Documents. n.d.). But, the 21 st-century definition of sustainability goes far beyond these narrow parameters. Today, it refers to the business environment as well as to the need to develop sustainable business models (McGregor, 2017).

Sustainability as a value is shared by many individuals and organizations who demonstrate this value in their policies, everyday activities and behaviours (the University of Alberta, n.d.). To remain relevant in the current market, or in other words to be sustainable, it is important that the company adapts its business model to the local market.

Sustainable development is a development that meets the needs of the present. For a pillar of sustainability to be strong, it must answer these questions with a yes: 1) Can it be sustainable? 2) Does it well support the goal of the system? (Glossary, Economic sustainability, n.d.). If these issues are transferred to the business environment, it would make the conclusion possible that there should be criteria necessary for measuring the current business environment and to answer these questions. In their research, the authors seek to achieve this goal and to define the most relevant elements of FinTech business models and to determine the impact of time, cost, flexibility and quality indicators on these elements to be able to provide specific criteria for answering the above-mentioned questions.

\section{Results}

All experts share the unanimous opinion that FinTech companies, which deal with creating their business models "are linked to sustainability goals and objectives" (interview with OC, 08.02.2019). It points out the necessity of measuring or testing the business model not only for completion but for its solvency. This justifies the need to regularly checking the business model not only for achieved results but also in the context of long-term availability of these results. This activity could be seen as an additional advantage for FinTech business modelling because companies could build a set of strategically important key elements with the aim to "optimize their business models, reduce risks or acquire 
resources if needed" (interview with PB, 12.01.2019). Additionally, these elements could be used as the basic elements for critical testing of business model performance in order to keep the model commercially viable.

After analyzing the answers obtained during the interviews, the authors could derive thematic categories that build the main elements of current business model dimensions in FinTech companies. These elements will be also used for obtaining the expected results of this research. In order to make it more transparent, the authors marked the areas: categories in dark grey; subcategories in grey and content items in white (Table 1).

Table 1. Elements of customer dimension (source: created by authors)

\begin{tabular}{|c|c|c|c|c|}
\hline $\begin{array}{l}\text { defined customer segments, } \\
\text { more than two segments }\end{array}$ & \multicolumn{3}{|c|}{$\begin{array}{l}\text { location is chosen, market knowledge to predict or anticipate, } \\
\text { needed to allocate }\end{array}$} & $\begin{array}{c}\text { acquisition, communication } \\
\text { ways are defined }\end{array}$ \\
\hline \multirow{2}{*}{$\begin{array}{l}\text { demand is explored and } \\
\text { documented, needs and } \\
\text { experience are researched } \\
\text { and coverable }\end{array}$} & Segments & Location, market knowledge & Acquisition & \multirow{2}{*}{$\begin{array}{l}\text { relationships could be } \\
\text { supported by the } \\
\text { company's processes and } \\
\text { are contributing to the } \\
\text { Cost Structure }\end{array}$} \\
\hline & $\begin{array}{r}\text { Demand, } \\
\text { needs, ex- } \\
\text { perience }\end{array}$ & Customer & $\begin{array}{l}\text { Input re- } \\
\text { lated to } \\
\text { costs }\end{array}$ & \\
\hline \multirow{2}{*}{$\begin{array}{l}\text { a perfect deadline, Urgency } \\
\text { in executing plans }\end{array}$} & Time & Impact factors & $\begin{array}{c}\text { Ability to } \\
\text { adapt }\end{array}$ & \multirow{2}{*}{$\begin{array}{l}\text { expectations can be } \\
\text { realized }\end{array}$} \\
\hline & \multicolumn{3}{|c|}{ Internal and external factors as impact factors are known } & \\
\hline
\end{tabular}

The obtained business model elements show, that FinTech companies have to focus their activities on customer needs, demand and experience while modelling their business and to take into account the communication ways which they use in order to reach their customer segments while implementing their business models. The choice of location and existing market knowledge is an essential aspect for selecting, analyzing and acquiring of particular customer segments and at the same for keeping the cost structure of the model. After deriving the elements, authors could distinguish the necessity of outspoken timely manner of executing plans and processes as well as of the flexibility, which is needed for being able to adopt the activities for changing customer demand and environment. This flexibility would be helpful for timely reacting to the impact of different risks and making punctual decisions about implementing alternative scenarios. While interviewing experts it was obvious, that the correlation between the derived elements and timely manner, flexibility, costs and quality can be seen as very relevant. As a result, the authors could draw the conclusion that these categories could be taken for derivation further success criteria in this research.

During the interviews, the authors could form a second set of characteristics or elements that the representatives of FinTech companies mentioned being of big importance in the sense of value creation within the business model as a result of their activities (Table 2).

Table 2. Elements of value dimension (source: created by authors)

\begin{tabular}{|c|c|c|c|c|}
\hline \multirow{2}{*}{$\begin{array}{l}\text { Constantly provided } \\
\text { monitoring of value } \\
\text { propositions }\end{array}$} & \multicolumn{3}{|c|}{ Engage value chain members including industry } & \multirow{2}{*}{$\begin{array}{l}\text { Specified for customer } \\
\text { segments }\end{array}$} \\
\hline & Monitoring & $\begin{array}{l}\text { Involvement of } \\
\text { the industry }\end{array}$ & $\begin{array}{l}\text { Customer } \\
\text { segments }\end{array}$ & \\
\hline $\begin{array}{l}\text { Portfolio of parallel innova- } \\
\text { tion processes }\end{array}$ & Innovation & Value & Flexibility & $\begin{array}{l}\text { Readiness to adopt for } \\
\text { changing client } \\
\text { expectations }\end{array}$ \\
\hline \multirow{2}{*}{ Benefit through the value } & Benefits & Measurement tools & & \multirow{2}{*}{ New resources are usable } \\
\hline & \multicolumn{3}{|c|}{ The measured value of working } & \\
\hline
\end{tabular}

The gathered information enabled the authors to draw a conclusion that it is almost impossible to create value without any relation to other business model dimensions, because value propositions, which are both qualitative and quantitative, refer to all of them and are directly or indirectly derived from them: it is possible to create value in terms of price, brand name, design and novelty and product usage by raising them to an expected and to the customer appealed level: such value elements as "Speed of service" (interview with OC, 08.02.2019) (Timely manner), "customer experience" (interview with MR, 10.02.2019) (Needs, demand), "effectiveness" (interview with MR, 10.02.2019) (input and output relation) and "customization" (interview with OC, 08.02.2019) (Flexibility) were acknowledged to be crucial to meet customer demand. But there was also a risk acknowledged, that the current value proposition delivered to a customer "... could be declined seriously or wouldn't be materialized" (interview with PB, 12.01.2019) and it would subsequently lead to loss of clients or "inability to attract new clients" (interview with MR, 10.02.2019). For this reason, market knowledge and constantly conducted monitoring of created values and their correspondence to customer segments as well as other related business model dimensions would be very recommendable. Flexibility and ability to use new resources for creating new value propositions could bring new benefits to the company. The main focus should be "the generation of a competitive advantage by means of valuable and difficult imitable resources" (interview with 
MR, 10.02.2019.). Such element as an involvement of the industry within the value business model dimension which refers to the market knowledge and lobby and provides new potential for consistently value creation process within the company could be combined with monitoring of the market circumstances using different measurement tools. As a result of these activities FinTech companies could gain information and contacts, get synergy effects and therefore make their positions on the current market more stable.

To sum the aforementioned up the authors can draw the conclusion that elements which companies have to focus on within the value business model dimension are innovations which correspond to benefits, customer segments that are gaining these benefits and innovations, measurement tools, which have to be set for monitoring the resources and involvement degree of the industry.

The next table constitutes the elements within the partner business model dimension which are relevant for creating and maintaining successful Partnerships for the company. These elements could be seen as core aspects that have to be regularly tested for performance and topicality assessment reasons for derived activities. The results of this evaluation and subsequently made management decisions would automatically contribute to the improvement of these activities therefore to the continuity of relationships with partner networks (Table 3 ).

Table 3. Elements of partner dimension (source: created by authors)

\begin{tabular}{|c|c|c|c|c|}
\hline \multirow{2}{*}{$\begin{array}{l}\text { The legal framework is } \\
\text { known and investigated }\end{array}$} & \multicolumn{3}{|c|}{ People, processes, equipment, analytic processes } & \multirow{2}{*}{$\begin{array}{l}\text { More attractive channels aligned } \\
\text { with customer } \\
\text { segments }\end{array}$} \\
\hline & $\begin{array}{l}\text { Regulatory } \\
\text { framework }\end{array}$ & Quality & Choice & \\
\hline $\begin{array}{l}\text { Partner contemplate the } \\
\text { providing of service in } \\
\text { terms of technology }\end{array}$ & Technology & Partner & Innovations & $\begin{array}{l}\text { looking for trends in emerging } \\
\text { economies or unrelated industries }\end{array}$ \\
\hline \multirow{2}{*}{$\begin{array}{l}\text { product creation, support, } \\
\text { monitoring, etc. }\end{array}$} & $\begin{array}{l}\text { Product and } \\
\text { service }\end{array}$ & $\begin{array}{c}\text { Involvement of } \\
\text { the industry }\end{array}$ & Lobby & \multirow{2}{*}{$\begin{array}{c}\text { trusted relationships with a wide } \\
\text { range of market authorities and } \\
\text { standard-setters }\end{array}$} \\
\hline & \multicolumn{3}{|c|}{ Participation of the industry } & \\
\hline
\end{tabular}

The authors were enabled to draw a conclusion that the creation of partnership relations is also one of the values for FinTech companies because partnerships provide "critical resources" (interview with MR, 10.02.2019) as well as lead to better results of the company. By building a network the company creates a network-based value that "depicts relations to external and internal actors" (interview with PB, 12.01.2019). For sustainable partnership network, there are external relations of importance, because, on the one hand, due to the constant information exchange the company could be updated with the latest trends and developments in the industry and on the market, on the other hand, new networks and innovative solutions can be created through new partnerships. It means that the stability of this business model dimension leads to new synergy effects and service combinations between the partners, thus, to new added value and innovations that could be invented. As can be seen from this figure one of the criteria correlates with the quality indicator. It could be explained by the fact that a week partnership is a risk for the company which leads to the inability of the whole business model when technologies, services and value creation directly depend and are based on built partnerships. Strong partnerships in foreign markets help to expand easier because partners are already operating in the market and "know the business culture of the area" (interview with MR, 27.01.2019). Customers who use the services of one company could benefit from the other company's services. On the one hand, this way makes a partnership of competitors possible; on the other hand, it provides the chance to cooperate for a long time.

As a conclusion follows to sum up that the regulatory framework within the country which indirectly determines the choice of the partners; the involvement intensity of the industry that establishes the lobby possibilities; innovations which correlate with created products, services and technology and support the quality of timely provided information within the partnership are the support points for creating this business model dimension more sustainable.

The financial part of a business model (see Table 4) is one of the most important parts which should include " $a$ clear vision of the future business finances from the very beginning" (interview with PB, 12.01.2019). At the same time, "it is impossible to predict exact numbers of sales, but you should know the approximate numbers you expect to get” (interview with MR, 10.02.2019).

Table 4. Elements for finance dimension (source: created by authors)

\begin{tabular}{|c|c|c|c|c|}
\hline \multirow{2}{*}{$\begin{array}{l}\text { Difference plan/fact not } \\
\text { more than } 10 \%\end{array}$} & \multicolumn{3}{|c|}{ Resources that the business must allocate } & \multirow{2}{*}{$\begin{array}{c}\text { Market variables, production } \\
\text { volumes, variable remuneration }\end{array}$} \\
\hline & Margin & Resources & Variables & \\
\hline $\begin{array}{l}\text { Justifying investments in } \\
\text { creative long-term projects }\end{array}$ & $\begin{array}{l}\text { Long term } \\
\text { projects }\end{array}$ & Finance & Reliance & $\begin{array}{l}\text { Reliance on the Partner on a } \\
\text { particular resource }\end{array}$ \\
\hline \multirow{2}{*}{ Consistently tax reporting } & Reporting & Reporting methods & Cash Flow & \multirow{2}{*}{ the inflows and outflows of money } \\
\hline & \multicolumn{3}{|c|}{ Streamlined reporting methods } & \\
\hline
\end{tabular}


The core elements within the finance business model dimension "interpret the results" (interview with OC, 08.02.2019) and make it possible to “...compare actual results to forecast" (interview with OC, 08.02.2019) as well as uncover the reasons for negative or positive deviations. The company should compare its financial results to those of other companies in the industry to see whether "it is performing above or below average" (interview with MR, 10.02.2019). It is possible with straightforward reporting methods, which enable the Management to make timely decisions and "change the direction" (interview with PB, 12.01.2019) if needed. Long term projects, which experts marked as one of the most important elements, ensure stable cash flow for the company. By means of appropriate reporting methods as well as variables and set up margins companies are able to assess the reliance on costs to the income. The assessment made in a timely manner is a possibility to the timely reaction on undesirable deviations.

The business model dimension, which was researched by the authors and which from the authors' point of view impacts the sustainability of the business model the most, is the management of the company because it helps to optimize business model elements within dimensions, influences moving towards the company's goals within the strategy. Management as a business model dimension presents how relevant it is for the company to fulfil commitments in all areas of the business model (Table 5).

Table 5. Elements for management dimension (source: created by authors)

\begin{tabular}{|c|c|c|c|c|}
\hline \multirow{2}{*}{$\begin{array}{l}\text { Transparently designed } \\
\text { communication internal } \\
\text { as well as external }\end{array}$} & \multicolumn{3}{|c|}{ Reducing the wastage which ultimately decreases costs } & \multirow{2}{*}{$\begin{array}{l}\text { Setting standards for different } \\
\text { partial models, modification } \\
\text { or development of a new } \\
\text { business model }\end{array}$} \\
\hline & Communication & Costs & Decisions & \\
\hline $\begin{array}{l}\text { Keeping track of the plans } \\
\text { and checking the results }\end{array}$ & $\begin{array}{c}\text { Plans and } \\
\text { Results }\end{array}$ & Management & $\begin{array}{c}\text { Observa- } \\
\text { tions }\end{array}$ & $\begin{array}{l}\text { Observing the relevant exter- } \\
\text { nal and internal conditions }\end{array}$ \\
\hline \multirow{2}{*}{$\begin{array}{l}\text { Creating new leadership } \\
\text { in a team }\end{array}$} & Leadership & Knowledge improvement & Analytics & \multirow{2}{*}{$\begin{array}{l}\text { Recognizing and anticipating } \\
\text { changes }\end{array}$} \\
\hline & \multicolumn{3}{|c|}{ Filling internal knowledge gaps } & \\
\hline
\end{tabular}

In the course of the research, the authors could figure out that all interviewed experts share similar opinion regarding the role and significance of the management while the company is modelling its business as well as after it has been implemented and has to be managed. As one of the most mentioned aspects for managing the company successfully, the initiative of the leaders was remarked. The initiative encourages other employees "to make their own plans and also implement them" (interview with OC, 08.02.2019). This approach could lead to satisfied employees who are involved in all processes and contribute to decision making. It has to be mentioned that the innovation processes according to the experts "begin also at the management stage" (interview with MR, 10.02.2019) and trigger and motivate employees to create "new ideas, new technology, new approaches and methods and consequently new products and services" (interview with OC, 08.02.2019). It is the management which provides employees with good environment and conditions, "recognizes the lack of knowledge and stimulates to research and to learn" (interview with OC, 08.02.2019). The result is "boosting productivity and profitability of the company" (interview with OC, 08.02.2019).

To sum the aforementioned up the authors concluded that the leadership as a prime mover; plans and results that lead to the ability to analyze costs and income; communicated decisions about the necessity to improve knowledge of the employees are the most common elements within the management business model dimension which support, direct and monitor its construction. The authors think that derivation the criteria from these elements into defined indicators for measuring performance and stability of this dimension could be used for building a basis for sustainability monitoring of business model elements or dimensions.

With the aim to explore which business model elements are affected by the probability of unsustainability the most and need to be especially highlighted, the authors have kindly asked the experts to analyze those elements in the context of time, costs, flexibility and quality. After these results were summarized authors were able to work out the criteria as they follow in this part of the research for partner, customer, value and finance dimension. The evaluation of the completion of these criteria as well as their importance rank while analyzing the model in the context of keeping the company's positions stable and sustain could be the subject of the next research of the authors.

By measuring the intensity of the indicator's impact on partnership dimension, based on the mentioning frequency during the interviews, it was evident, that all indicators influence this dimension and can be used for creating of measurement criteria. Quality as an indicator is one of the key indicators: the quality of the services; technological support; consulting, etc., is also related to the possibility to attract customers to the company and their desire to use the existing services for a longer period of time. It was possible for the authors to conclude that quality is a prerequisite for a good company reputation: The higher the quality of the partnership, the longer it is possible for the company to exist on the market. For measuring the performance of this business model dimension, the authors propose to FinTech companies to use predefined quality criteria for all elements defined in the first part of this research (Table 6). 
Table 6. The influence of indicators and recommendable criteria for partner business dimension (source: created by authors)

\begin{tabular}{|c|c|c|c|c|}
\hline \multirow{2}{*}{ Elements of the partner business model dimension } & \multicolumn{3}{|c|}{ Indicators } \\
\cline { 2 - 5 } & Time & Costs & Flexibility & Quality \\
\hline Regulatory framework & $\mathrm{x}$ & $\mathrm{x}$ & $\mathrm{x}$ & $\mathrm{x}$ \\
\hline Technology & $\mathrm{x}$ & $\mathrm{x}$ & $\mathrm{x}$ & $\mathrm{x}$ \\
\hline Product and service & $\mathrm{x}$ & $\mathrm{x}$ & $\mathrm{x}$ & $\mathrm{x}$ \\
\hline Quality & $\mathrm{x}$ & $\mathrm{x}$ & $\mathrm{x}$ \\
\hline Choice & $\mathrm{x}$ & $\mathrm{x}$ & $\mathrm{x}$ & $\mathrm{x}$ \\
\hline Innovations & & & $\mathrm{x}$ \\
\hline Lobby & & & & $\mathrm{x}$ \\
\hline
\end{tabular}

\section{CRITERIA}

- The company is aware of the regulatory framework that is actual for the current market and necessary for its activities, the framework is systematically monitored and communicated to the management of the company;

- Timely executed identification of legal risks and their influence on the company's activities is a permanent process that leads to the improvement of the company's legal background and qualitatively managed partnerships;

- The company has defined the costs which are necessary for technological solutions needed for the company's activities within the partnership dimension;

- Technology qualitatively supports all processes which are maintained for building and keeping partnerships;

- Costs for partnerships are related to the income which is gained through them;

- Partners are segmented and correspond to the company's activities, processes, products and services as well as technological capabilities;

- The company defined the role of the lobby for its market positions or other economic advantages and knows which partner or possibilities could be used.

The indicator which impacts the customer dimension the most is the indicator of costs. On the one hand, this can be explained by the fact that all activities performed by FinTech company focus on the provision of services to customers: these are resources which are used for attraction of the customers, identification and satisfaction of customer needs, etc. It can be also explained by the fact that the source from which the costs can be covered is the income from the customer. As known, activities of FinTech companies are based on technology while production and provision of services as well as on the development of technologies. Technologies are related to significant costs that a company's management should also take into account while analyzing the income and outcome relations constantly. It is a question of future income from the customer, pricing policy and diversity of customer segments as well. Following criteria that FinTech companies could use for measuring performance within the customer business dimension are possible (Table 7).

Table 7. The influence of indicators and recommendable criteria for customer business dimension (source: created by authors)

\begin{tabular}{|c|c|c|c|c|}
\hline \multirow{2}{*}{ Elements of customer business model dimension } & \multicolumn{4}{|c|}{ Indicators } \\
\cline { 2 - 5 } & Time & Costs & Flexibility & Quality \\
\hline Customer segments & $\mathrm{x}$ & $\mathrm{x}$ & $\mathrm{x}$ & $\mathrm{x}$ \\
\hline Location, market knowledge & & $\mathrm{x}$ & $\mathrm{x}$ & $\mathrm{x}$ \\
\hline Acquisition & $\mathrm{x}$ & $\mathrm{x}$ & $\mathrm{x}$ & $\mathrm{x}$ \\
\hline Flexibility & $\mathrm{x}$ & $\mathrm{x}$ & $\mathrm{x}$ & $\mathrm{x}$ \\
\hline Timely manner & $\mathrm{x}$ & $\mathrm{x}$ & $\mathrm{x}$ & $\mathrm{x}$ \\
\hline Impact factors & & $\mathrm{x}$ & $\mathrm{x}$ & $\mathrm{x}$ \\
\hline Demand, needs, experience & & & \\
\hline
\end{tabular}

\section{CRITERIA}

- Customer segments are defined in terms of location and acquisition costs, the choice of customer segments is based on persuasive arguments and capabilities;

- Communication with customers contributes to the feedback about their expectations and needs;

- Market knowledge is present in the company and is the topic of consistent research;

- The demand, needs and expectations are evaluated and build the basis for the company's activities;

- The created value of products and services corresponds to the demand, needs and expectations of the customers;

- The acquisition of the customers is possible in a short time through determined channels by using technological capabilities;

- Impact factors that influence the acquisition, servicing the customers are systematically identified, communicated within the company and controlled for their mitigation;

- Created products and services correspond to different customer segments and are technologically adaptable in case of any changes, the comparison is systematically conducted;

- There are employees who are responsible for maintaining, developing, building and managing partnership-networks. 
The quality indicator also influences the value dimension in the business model according to the measurements made by the authors. The authors conclude, that the value that FinTech companies create while operating and providing their services is value to stakeholders as long as they percept it to be. This view is based on the benefits that stakeholders derive from the value created by the company and that make it possible to operate successfully as well as different from other market participants. Additionally, companies have to determine the quality criteria that they want to meet in different business areas before the model is implemented. Criteria that the authors propose for FinTech companies are as follow (Table 8).

Table 8. The influence of indicators and recommendable criteria for value business dimension (source: created by authors)

\begin{tabular}{|c|c|c|c|c|}
\hline \multirow{2}{*}{ Elements of value business model dimension } & \multicolumn{4}{|c|}{ Indicators } \\
\hline & Time & Costs & Flexibility & Quality \\
\hline Monitoring with appropriate measurement tools & $\mathrm{x}$ & $\mathrm{x}$ & & $\mathrm{x}$ \\
\hline Customer segments & $\mathrm{x}$ & & $\mathrm{x}$ & $\mathrm{x}$ \\
\hline Benefits & & & & $\mathrm{x}$ \\
\hline Resources & $\mathrm{x}$ & $\mathrm{x}$ & & $\mathrm{x}$ \\
\hline Flexibility & $\mathrm{x}$ & & $\mathrm{x}$ & $\mathrm{x}$ \\
\hline Innovation & $\mathrm{x}$ & & & $\mathrm{x}$ \\
\hline \multicolumn{5}{|c|}{$\begin{array}{l}\text { CRITERIA } \\
\text { Creating value is a business priority; } \\
\text { The generated value is focused on stakeholders' needs and expectations; } \\
\text { All employees of the company are involved in the value creation process; } \\
\text { The company systematically monitors the value creation process and correlates them with customer demand, market } \\
\text { situation and company revenue structure; } \\
\text { The value created has a positive measurable impact on the company's income, image and customer satisfaction. }\end{array}$} \\
\hline
\end{tabular}

The impact of indicators on the financial dimension is also different according to experts' answers. As can be seen, the greatest impact on this dimension has a time indicator. The authors explain it with the necessity of timely financial controlling and supervising; otherwise, the company is threatened with insolvency or financial institution sanctions. The second explanation would be that FinTech companies are direct participants of the financial sector and the requirements they have to meet regarding the understanding of financial aspects qualitatively correspond to their nature. The criteria proposed by the authors for the financial dimension of companies are presented in Table 9 .

Table 9. The influence of indicators and recommendable criteria for finance business dimension (source: created by authors)

\begin{tabular}{|c|c|c|c|c|}
\hline \multirow{2}{*}{ Elements of finance business model dimension } & \multicolumn{4}{|c|}{ Indicators } \\
\hline & Time & Costs & Flexibility & Quality \\
\hline Margin, variables, reliance & & & $\mathrm{x}$ & \\
\hline Long term projects & $\mathrm{x}$ & $\mathrm{x}$ & $\mathrm{x}$ & $\mathrm{x}$ \\
\hline Reporting and reporting methods & $\mathrm{x}$ & $\mathrm{x}$ & & $\mathrm{x}$ \\
\hline Cash flow & $\mathrm{x}$ & & & \\
\hline Resources & $\mathrm{x}$ & $\mathrm{x}$ & $\mathrm{x}$ & $\mathrm{x}$ \\
\hline \multicolumn{5}{|c|}{$\begin{array}{l}\text { CRITERIA } \\
\text { The company has tools and instruments at its disposal to timely document, analyze and control its costs; } \\
\text { The company engages in long-term projects that generate long-term profit for it; } \\
\text { Company expenses are lower than their income; } \\
\text { The company controls the costs of resources and their appropriate usage; } \\
\text { Cash flow corresponds to the company's planned and real activities. }\end{array}$} \\
\hline
\end{tabular}

As is evident, the customer dimension within a working business model is affected by time and costs the most. It means that the company has to define the sustainability indicators in these dimensions at first in order to keep, monitor, ensure and measure their status quo and prospects.

In the matter of costs, or rather, the aspects which produce the most costs, customer and finance dimensions are significantly influenced. The authors explain this with the necessity to provide a measure of the effectiveness of actions and decisions in order to move the activity or the process towards a more sustainable state. By creating the sustainability indicators in the context of costs related to the customers, management decisions and initiative, the company can use and misuse the information and results in order to improve the assessment and keep the input and output well balanced.

As is evident, quality as a very important aspect that affects income stability, the satisfaction of customers and its understanding by stakeholders. Speaking about the sustainability or defining of sustainability indicators, the company 
has to pay attention to the indicators, which measure and monitor the predefined quality goals and parameters. With them, actionable solutions with ongoing support for the business model dimensions would be more transparent and professional.

\section{Conclusions}

To sum the aforementioned up and be able to draw certain conclusions as a bottom line it has to be noticed that:

There are particularly important elements in every business model dimension, that ensure the completion of the business model dimension and consequently the whole business model. If the company is aware of these elements, it can create its business model more confidently.

With the aim to create a business model that would enable the company operating on the chosen market for a long period of time, the company must identify those elements of the business model that are influenced by the risk of getting unsustainable the most. By knowing these elements, the company can use them as pillars for creating a business model and as benchmarks for developing their performance criteria.

Every element of the business model is influenced by time, costs, flexibility and quality factors. If the company is informed about the intensity of their influence it can rank the importance of these elements within the business model dimension and consequently develop criteria for each element in order to determine its impact and its consequences.

Criteria for measuring the performance of the business model of the company make it possible to manage the risk of getting commercially nonviable, or in other words, to support the sustainability of the business model.

\section{References}

Banking Environment Initiative (BEI). (2017). Catalyzing FinTech for sustainability. Lessons from multi-sector innovation. Retrieved from https://www.cisl.cam.ac.uk/resources/publication-pdfs/catalysing-fintech-for-sustainability.pdf

Bell, S., \& Morse, S. (2008). Sustainability indicators: Measuring the immeasurable (2nd ed., pp. 145-147). London: Earthscan.

Bernard, H. R. (1988). Research methods in cultural anthropology. Beverly Hills: Sage. 48.

Bieger, T., \& Reinhold, S. (2011). Das wertbasierte Geschaftsmodell - ein aktualisierter Strukturansatz [The Web-based Business Modell - actual structural approach]. Springer, Berlin, 11-70.

Bocken, N. M. P., Rana, P., \& Short, S. W. (2015). Value mapping for sustainable business thinking. Journal of Industrial and Production Engineering, 32(1), 67-81. https://doi.org/10.1080/21681015.2014.1000399

Bondarenko, P. (PB). (2019, January 12). Personal Interview. Executed by the authors.

Castilla-Rubio, C. J., Zadek, S., \& Robins, N. (2016). FinTech and Sustainable development. Assessing the implications. Inquiry report. UNEP Inquiry.

Chernishews, O. (CO). (2019, February 8). Personal Interview. Executed by the authors.

Glossary, Economic sustainability. (n.d.). Retrieved from https://www.thwink.org/sustain/glossary/EconomicSustainability.htm

EBSCO host, $180(216,1), 16$.

Gassmann, O., Frankenberger, K., \& Csik, M. (2013). Geschäftsmodelle entwickeln 55 innovative Konzepte mit dem St. Galler Business Model Navigator. München: Hanser Verlag.

Konnertz, L., Rohrbeck, R., \& Knab, S. (2011, June). How collaborative business modeling can be used to jointly explore sustainability innovations. In ISPIM Annual Conference. Hamburg, Germany.

Latawiez, A. E., \& Agol, D. (2015). Sustainability indicators in practice (pp. 93-162). https://doi.org/10.1515/9783110450507

Martinsone, K., Pipere, A., \& Kamerāde, D. (2016). Pētniecība. Teorija un prakse [Research. Theory and praxis]. Rīga, p. 375.

Matzler, K. (2016). Digital Disruption: Wie Sie Ihr Unternehmen auf das digitale Zeitalter vorbereiten [How to prepare Your enterprise for digital age]. Kindle Edition, 964-972.

McGregor, J. (2017). Business model innovation - The secret weapon of your sustainability strategy. Blog Business Model Innovation. Retrieved from https://bluetribe.co/business-model-innovation-the-secret-weapon-of-your-sustainability-strategy/

Menat, R. (2016). Why we're so excited about FinTech. In S. Chishti, \& J. Barberis (Eds.), The FinTechBook. The financial technology handbook for investors, entrepreneurs and visionaries (Chapter 2, pp. 10-12). Chichester. https://doi.org/10.1002/9781119218906.ch2

Mitchell, D., \& Coles, C. (2003). The ultimate competitive advantage of continuing business model innovation. Journal of Business Strategy, 24(5), 16-26. https://doi.org/10.1108/02756660310504924

Müller, F. (2017). Der digitale Wandel in der Finanzbranche: Wie Fintechs, Robo Advisor und Blogger die Banken schlagen, pp. $275-281$.

Osterwalder, A., Pigneur, Y., \& Tucci, C. L. (2005). Clarifying business models: Origins, present, and future of the concept. In Communications of the association for information systems (Vol. 16, pp. 1-25). https://doi.org/10.17705/1CAIS.01601

Roeder, J., Cardona, D. R., Palmer, M., Werth, O., Muntermann, J., \& Breitner, M. H. (2018). Make or break: Business model determinants of FinTech Venture success. 1221-1229.

Rowe, A., Bansal, T., \& Bansal, T. (2013). Ten steps to sustainable business in 2013. Ivey Business Journal. Retrieved from https://iveybusinessjournal.com/publication/ten-ways-to-help-companies-become-sustainable-in-2013/

Rudovitsch, M. (MR). (2019, February 10). Personal Interview. Executed by the authors. 
Schallmo, D. R. A. (2013). Geschaftsmodelle erfolgreich entwickeln und implementieren [Successful Development and Implementation of Business Modells], (Kindle edition, pp. 1142-1557).

Sustainability problem. (n.d.). Glossary: Economic sustainability. Retrieved from https://www.thwink.org/sustain/glossary/EconomicSustainability.htm

UN Documents (n.d.). Our common future: Report of the World Commission on environment and development. Retrieved from http://www.un-documents. net/ocf-02.htm

University of Alberta, office of sustainability. (n.d.). Retrieved from https://www.mcgill.ca/sustainability/files/sustainability/whatis-sustainability.pdf

Van Stel, A., Carree, M., \& Thurik, R. (2005). The effect of entrepreneurial activity on national economic growth. Small Business Economics, 24(3), 311-321. https://doi.org/10.1007/s11187-005-1996-6

Wisniewski, M. (2016). Fintechs team up to become more banklike. American Banker. Business Source Complete. 